\title{
Ortaokul Öğrencilerinin Mutluluklarının Eğitim Stresi ve Okul Yaşam Kalitesi Tarafından
}

\author{
Yordanması
}

\author{
Prediction of Middle School Students' Happiness by Educational Stress and Quality of School \\ Life
}

\author{
Alim KAYA $^{1} \quad$ Mehtap SEZGIN ${ }^{2}$
}

\begin{tabular}{lll}
\hline Başvuru Tarihi: 07.09.2016 $\quad$ Yayına Kabul Tarihi: 08.03.2017 $\quad$ DOI:10.21764/efd.42917 \\
\hline
\end{tabular}

Özet: $\mathrm{Bu}$ araştırma, eğitim stresi ve okul yaşam kalitesinin ortaokul öğrencilerinin okul ortamındaki mutluluklarını manidar şekilde yordayıp yordamadığını incelemek amacıyla yapılmıştır. Araştırmada çeşitli demografik verilerin öğrenilmesi amacıyla Kişisel Bilgi Formu, öğrencilerin akademik nedenlerden kaynaklanan stres düzeylerini ölçmek amacıyla Eğitim Stresi Ölçeği, öğrencilerin okullarındaki yaşama ilişkin algılarını ölçmek amaciyla Okul Yaşam Kalitesi Ölçeği,öğrencilerin okuldaki mutluluk düzeylerini belirlemek amacıyla Okul Çocuklarının Mutluluk Envanteri kullanılmıştır. Araştırmanın çalışma grubunu 2015-2016 eğitim-öğretim yılında Türkiye'nin Akdeniz bölgesinde yer alan bir il merkezine bağlı devlet ortaokullarında öğrenim gören 411 öğrenci oluşturmaktadır. Verilerin analizi için aşamalı regresyon analizi yöntemi kullanılmıştır. Analiz sonuçlarına göre eğitim stresi ve okul yaşam kalitesi boyutlarından çalışma baskısı, statü, okula yönelik duygular, beklentiye karşı umutsuzluk, öğretmen boyutları birlikte ortaokul öğrencilerinin mutluluk düzeylerinin \%31'ini açıklamaktadır. Modele dahil edilen çalışma baskısı, statü, okula yönelik duygular, beklentiye karşı umutsuzluk ve öğretmen boyutları birlikte ortaokul öğrencilerinin mutluluk düzeylerini 0.01 anlamlılık düzeyinde manidar bir şekilde yordamaktadır. Bu modele göre ortaokul öğrencilerinin mutluluk düzeylerinin manidar yordayıcılarının göreli olarak önem sırası çalışma baskısı, statü, okula yönelik duygular, beklentiye karşı umutsuzluk ve öğretmen boyutlarıdır.

Anahtar Sözcükler: Mutluluk, eğitim stresi ve okul yaşam kalitesi

\begin{abstract}
The aim of this present study is to reveal whether both educational stress and quality of school life together predict the happiness of middle school students at school setting at a significant level. Within the scope of the study various scales were conducted for the data collection; Personal Information Formis for the collection of demografic features, Educational Stress Scale for the measurement of the stress level of the students caused by academic reasons, Quality of School Life Scale for the measurement of students' perceptions about the school life, School Children's Happiness Inventory for the measurement of the happiness level of students at school. The participants of this research consist of 411 middle school students studying at state schools of a city center in Mediterranean Region of Turkey in 2015-2016 academic year. Stepwise regression has been preferred among multiple regression analysis methods for data analysis. The analyses reveal that within the dimensions of educational stress and quality of school life, study pressure, status, affections towards the school, desperateness towards expectancy and teachers related dimensions explain \%31 of happiness level of middle school students. Included into the model, study pressure, status, affections towards the school, desperateness towards expectancy and teachers related dimension altogether predict the happiness level of middle school students at 0.01 significance level. According to this model, the order depending on significance levels among middle school students' happiness predictors is as follows: "study pressure, status, affections towards school, desperateness of expectancy, teachers".
\end{abstract}

Key words: Happiness, educational stress and quality of school life

\footnotetext{
${ }^{1}$ Prof. Dr., Mersin Üniversitesi, Eğitim Fakültesi, Eğitim Bilimleri Bölümü, Rehberlik ve Psikolojik Danışmanlık Anabilim Dalı, alimkaya32@gmail.com

${ }^{2}$ Araş.Gör., Mersin Üniversitesi, Eğitim Fakültesi, Eğitim Bilimleri Bölümü, Rehberlik ve Psikolojik Danışmanlık Anabilim Dalı, mehtapsezgin@gmail.com
} 


\section{Giriş}

Pek çok filozof ve sosyal bilimci mutluluk veya bir başka ifade ile iyi oluşun ne olduğu ile ilgilenmişlerdir. Yapılan mutluluk tanımlarıüç farklı kategoride sınıflandırılmıştır. İlk olarak mutluluk veya iyi oluş erdemlilik ve kutsallık gibi dışsal ölçütlerle tanımlanmaktadır. İkinci olarak mutluluk kavramıinsanların yaşamlarını olumlu değerlendirmelerine neyin öncülük ettiğiyle, iyi yaşamın ne olduğuna yönelik standartlarla, yaşam doyumuyla ilişkilendirilmekte ve tanımlanmaktadır. Üçüncü olarak mutluluk memnun edici duygusal deneyimlerle ilişkilendirilmektedir(Diener, 1984). Mutluluk, tüm dünyada pek çok insan tarafından iyi bir yaşam ölçütü olarak kabul edilen önemli bir yaşam ideali olarak görülmektedir (Türkdoğan, 2010).

Aristo'nun ufuk açıcı görüşlerinden bu yana mutluluk ile ilgili pek çok kuram ileri sürülmüştür. Bu kuramlar ihtiyaç ve amaçların doyumu, süreç veya aktivite kuramları, genetik ve kişilik eğilimleri kuramları olarak üç grupta sınıflandırılmaktadır. İhtiyaçların ve amaçların doyumu kuramına göre gerilimin azaltılması, biyolojik ve psikolojik ihtiyaçların ve amaçların doyurulması kişiyi mutlu etmektedir. Mutluluğu bir süreç ve aktivite olarak ele alan kuramlar, bir aktivite ile ilgilenmenin veya bir görevi yerine getirmenin kişiyi mutlu ettiğini belirtmektedirler. Genetik ve kişilik eğilimleri kuramları bireyin iyi olmasının kalıtsal ve sabit bir olgu olduğunu savunmaktadır. İyi olmanın, genetik ve kişilik özelliklerinden kaynaklandığını savunmaktadırlar (Diener, Oishi ve Lucas, 2002).

Toplumların geleceğini oluşturacak olan çocukların akademik, sosyal ve psikolojik gelişimlerinin ön koşullarından biri okullarında kendilerini mutlu ve güvende hissetmeleridir (Önder ve Sarı, 2009). Okul çağı çocuklarının mutluluğu, belirli çevresel faktörler karşısında okuldan beklentiler ve bireysel ihtiyaçların uyumu ile oluşan olumlu duygusal bir yaşantı olarak ifade edilmektedir (Engels, Aelterman, Petegem ve Schepens, 2004; akt. Telef 2014).Ancak, okul yaşamı boyunca aşırı ders yükü, sınav baskısı, başarı kaygısı, ailenin yüksek beklentileri ve baskısı öğrenciler için stres faktörleridir (Li ve Zhang, 2008, akt. Özdemir ve Özdemir, 2015). Stres, kişiyi zorlayan, kısıtlayan, engelleyen olaylar ve durumlar karşısında verdiğimiz tepkilerin tümüdür (Demirci, Engin, Bakay ve Yakut, 2013).Akademik stres ise kişiden beklenen akademik taleplerin birleşiminin bireye uygun olmaması veya bireyin uyum sağlayabileceği beceri ve yetenekleri aşmasıdır (Wilks, 2008). Stres faktörünün bireyin psikolojik iyi olma düzeyini etkilediği bilinmektedir (Akın, 2013).

Çocukların genel iyi olma hallerinin göstergelerinden bir diğeri de okul yaşam kalitesidir (Karatzias, Papadioti Athanasiou, Power ve Swanson, 2001). Okul yaşam kalitesini ilk kavramsallaştıran Epstein ve McPartland (1976)'a göre okul yaşam kalitesi öğrencilerin okuldan genel memnuniyetleri, okula bağlılıkları ve öğretmenlerine olan tutumlarını ifade eden öğrenci tepkileridir (Akt. Ayık, Ataş-Akdemir, 2015). Okul 
yaşam kalitesi araştırmacılar tarafından farklı boyutlara ayrılarak ele alınmıştır. Sarı (2012a)'ya göreöğretmen-öğrenci ilişkileri, öğrenci-öğrenci ilişkileri, okula yönelik duygular, okul yönetimi, çocuğun okulda kendini ne kadar değerli ve önemli hissettiği ile ilgili olan statü durumu öğrencilerin okul yaşam kalite algılarını oluşturmaktadır. Öğretmen-öğrenci ve öğrenci-öğrenci arasında sağlıklı iletişim kanallarının kurulması ve işleyişi öğrenme ortamının nitelikli bir yapıda olmasını sağlar (Erdoğan, 2011). Okulda bilgi aktarma ve öğrenim sürecini yöneten, sınıf içi düzen ve disiplini sağlayan en etkin kişi öğretmendir. Grubun uyumunu sağlamak, her öğrenciyi bu uyum içerisinde etkin, yaratıcı ve mutlu bir birey olmaya yönlendirmek, öğretmenin yeteneğine, anlayışına, sevecenliğine bağlıdır (Yavuzer, 2011). Gordon'a (2013) göre öğretmen-öğrenci ilişkisinin iyi olabilmesi için öğrenci ve öğretmenin doğrudan iletişim kurabilecekleri ortama sahip olmaları, birbirlerini önemsemeleri, birbirlerinin farklı birer kişiliğe sahip olduklarını kabul etmeleri, birbirlerine saygı duymaları ve bağımlı olmaya karşı birbirlerine gereksinim duymaları önemlidir. Öğrenci-öğrenci etkileşimi ise çocukların toplumsallaşması, anti-sosyal davranışlardan uzak durması, gelecekteki ruhsal sağlıkları, uygun cinsiyet rolü kimliği kazanmaları, başkalarını daha iyi anlamaları ve ben merkezlikten uzaklaşmaları, eğitim isteği ve akademik başarılarının yükselmesinde rol oynar. Öğrenciöğrenci etkileşiminin yapıcı sonuçlar vermesi için etkileşimin düşmanlık ve nefret duygularını değil, kabullenme ve özen gösterme gibi olumlu duyguları geliştirecek nitelikte olması gerekir (Yılmaz, 2001). Okul yapısı ve okul yönetimi de öğrencilerin memnuniyetinde ve mutluluğunda etken faktörlerdir. Öğrencilerin kendilerini daha rahat hissedecekleri ortamlar, geniş derslikler, araç gereç donanımının olması, okulun fiziksel yapısının öğrencilerin gelişimlerine uygunluğu, okulu daha sevilebilir ve mutlu bir ortam haline getirebilir (Döş, 2013). Okul yönetiminin görevi ise okulu amaçlarına uygun olarak yaşatmaktır. Okulu amaçlarına uygun olarak yaşatmak örgütteki insan ve madde kaynaklarını en verimli şekilde kullanmakla gerçekleşir (Ünal ve Ada, 1999). Okul müdürünün öğrencilere yakın olması, öğrencilerle iletişim halinde olması, onlarlakonuşması ve onları dinlemesi, onlarla şakalaşması, okulda iyi bir iklim oluşturması öğrencilerin okullarında mutlu olmalarında etkilidir (Döş, 2013).Çocuklar zamanlarının önemli bir bölümünü geçirdikleri okullarda özel bir yere sahip olduklarını, öğretmenleri ve arkadaşları için değerli olduklarını hissetmek isterler. Çocuklar kendilerini değerli hissettikleri ölçüde kendilerine güvenirler ve kendine güvenleri, çevreleriyle olan ilişkilerini, mutluluklarını ve yaşam kalitelerini belirler (Sarı, 2012a). Her çocuğun kendini duygusal ve sosyal açıdan güvenli hissedebileceği, korkularını ve güvensizliğini yenebileceği bir ortama ihtiyacı vardır (Yavuzer, 2004).

Okul ortamında çocuğun mutlu olması çocuğun hem akademik alanda hem de sosyal alanda başarılı olmasını sağlar (Bird ve Markle, 2012). Dolayısıyla okul ortamında çocuğun mutlu olması aslında eğitim programlarının asıl amacı olan sosyal ve akademik açıdan başarılı kişilerin yetiştirilme hedefinin gerçekleşmesini sağlayacaktır. Bu nedenle okul ortamında çocuğun mutluluğunu açıklayan değişkenlerin araştırılıyor olması önemlidir. Daha önce yapılan araştırmalarda öğrencilerin mutluluk düzeyi ile stres, öğretmen ilişkileri, akran desteği, okula yönelik tutum, benlik saygısı arasındaki ilişkiler ayrı ayrı ele 
alınmıştır. Ancak, alan yazında öğrencilerin mutluluk düzeyi ile ilişkili olan bu değişkenlerin birlikte ele alındığı, mutluluk düzeyinin yordanmasına ilişkin bir araştırmaya rastlanmamıştır. Bu araştırmanın amacı,eğitim stresi ve okul yaşam kalitesinin birlikte ortaokul öğrencilerinin okul ortamındaki mutluluklarını manidar bir şekilde yordayıp yordamadığını, yorduyor ise bunun düzeyinin ne olduğunu ortaya koymaktır.

\section{Yöntem}

Araştırma Modeli

Eğitim stresi ve okul yaşam kalitesinin ortaokul öğrencilerinin mutluluklarını yordama düzeyini incelemek amacıyla yapılan bu araştırmada ilişkisel araştırma modeli kullanılmıştır. İlişkisel araştırma, iki ya da daha fazla değişken arasındaki ilişkileri belirlemeye, neden-sonuç ile ilgili ipuçlarını elde etmeye ve ilişki tür ya da türlerinin ne dereceye kadar var olduğunu bulmaya çalışır (Büyüköztürk, Çakmak, Akgün, Karadeniz ve Demirel 2009).

Araştırmanın Çalışma Grubu

Araştırmanın çalışma grubunu 2015-2016 eğitim-öğretim yılında Türkiye'nin Akdeniz Bölgesinde yer alan biril merkezine bağlı devlet ortaokullarındanseçkisiz örnekleme yöntemiyle seçilmiş olan dört ortaokulda öğrenim gören 411öğrenci oluşturmaktadır. Bu öğrencilerinyaş ortalaması 12.53 ve yaş aralığı 10 ile 16'dır.Çalışma grubunun \%28'i (n:115) 5.sınıf öğrencisi, \%21.7'si (n:89) 6.sınıf öğrencisi, \%31.4'ü (n: 129) 7.sınıf öğrencisi ve \%19’u (n:78) 8.sınıf öğrencisidir. Ayrıca çalışma grubunun \%53’ü kız (n:218) ve $\% 47$ 'si (n:193) erkek öğrencilerden oluşmaktadır.

Araştırmada Kullanılan Veri Toplama Araçları

Araştırmacılar tarafından hazırlanan kişisel bilgi formu aracılığıyla, katılımcıların cinsiyetleri, yaşları ve sınıf düzeylerine ilişkin bilgiler toplanmıştır.Araştırmada Eğitim Stresi Ölçeği, Okul Yaşam Kalitesi Ölçeği ve Okul Çocuklarının Mutluluk Envanteri kullanılmıştır.

Ĕgitim Stresi Ölçeği (ESÖ) :Sin, Dunne, Hou ve Xu (2011) tarafından 12-18 yaş aralığındaki öğrencilerin akademik nedenlerden kaynaklanan stres düzeylerini ölçmek amacıyla geliştirilmiş, Türkçe'ye Seçer, Veyis ve Gökçen(2015) tarafından uyarlanarak geçerlilik ve güvenirlilik çalışmaları yapılmıştır. Ölçekten alınan yüksek puanlar akademik süreçlerden kaynaklanan stresin arttı̆̆ını göstermektedir. Ölçek çalışma baskısı, ders yükü, başarı kaygısı ve beklentiye karşı umutsuzluk alt boyutlarını içeren 4 faktörlü bir yapıya sahiptir. Ölçekteki alt boyutlara ek olarak ölçek toplam puanda vermektedir.Ölçeğin güvenirlilik çalışmaları için Cronbach alfa iç tutarlılık katsayısı .85, (alt boyutlar için sırasıyla .73, .75, .76, .75); Sperman Brown iki yarı güvenirlik katsayısı ise .82 (alt boyutlar için sırasıyla .72, .74, .74, .71) olarak bulunmuştur. Bu araştırmanın veri setine göre eğitim stresi ölçeğinin güvenirlilik çalışmaları için Cronbach alfa iç tutarlılık katsayısı.72, (alt boyutlar için sırasıyla .56, .63, .63, .59); Eğitim stres ölçeği, için yapılanAFA sonucunda 
toplam varyansın \% 62.51'ini açıklayan dört faktörlü yapı elde edilmiştir. Madde faktör yükleri .44- .79 arasındadır. Doğrulayıcı faktör analizi sonucunda dört boyutlu yapının iyi uyum verdiği bulunmuştur $(\mathrm{RMSEA}=.054, \mathrm{RMR}=.013, \mathrm{NFI}=.90, \mathrm{CFI}=.96, \mathrm{IFI}=.97, \mathrm{RFI}=.92, \mathrm{AGFI}=.90, \mathrm{GFI}=.92)$ (Seçer, Veyis ve Gökçen, 2015).

Okul Yaşam Kalitesi Ölçeği (OYKÖ):öğrencilerin okullarındaki yaşama ilişkin algılarını ölçmek amacıylaSarı tarafından2007 yılında geliştirilmiş ve 2012 y1lında revize edilmiştir. Ölçek öğretmenler, öğrenciler, okula yönelik duygular, okul yönetimi ve statü alt boyutlarını kapsayan 5 faktörlübir yapıya sahiptir.Alt boyutlardan alınan yüksek puanlar ilgili boyut açısından okul yaşam kalitesinin yüksekliğine işaret etmektedir. Ölçeğin güvenirlilik ve geçerlilik çalışmalarıyaş ortalaması12 olan öğrenci grubu yapılmıştır. Alt boyutlar için Cronbach Alfa iç tutarlılık katsayıları sırasıyla .83, .83, .77., .77. .69'dur. Bu araştırmanın veri setine göre alt boyutlar için Cronbach Alfa iç tutarlılık katsayıları sırasıyla .78, .78, .84, .76. .76'dır. Belirtilen beş alt boyut toplam varyansın \%46.92'sini açıklamaktadır. Madde faktör yükleri .51 ile -.76 arasındadır. Yapılan doğrulayıcı faktör analizine göre elde edilen $\left(X^{2} / s d=3.66\right)$ değerininmodelin uyum iyiliğine işaret ettiği belirtilmiştir. DFA sonucunda elde edile uyum iyiliği kriterleri de modelin verilere iyi uyum gösterdiğine işaret etmektedir (RMSEA=.068, NNFI=.94, NFI=.93, SRMR=.067, $\mathrm{CFI}=.95$, GFI=.83) $($ Sar1, 2012a).

Okul Çocuklarının Mutluluk Envanteri (OÇME):Ivens (2007) tarafından okul çocuklarının okuldaki mutluluk düzeylerini belirlemek için geliştirilmiş ve Telef (2014) tarafından Türkçe'ye uyarlanmış, geçerlilik ve güvenirlilik çalışmaları yapılmıştır. Ölçme aracı 8 ile 15 yaş aralığında çocuklara uygulanmakta olan envanterden alınan yüksek puanlar mutluluk düzeyinin yüksek olduğuna işaret etmektedir. Envanterin güvenirliliği için Cronbach Alfa iç tutarlılık katsayısı.92 olarak saptanmıştır. Bu araştırmanın veri setine göre ölçeğin Cronbach Alfa iç tutarlılık katsayısı .90 olarak hesaplanmıştır. Envanterin yapı geçerliliği çalışması için açımlayıcı ve doğrulayıcı faktör analizi çalışmaları yapılmıştır. İki faktörün açıkladığı toplam varyans \%39'dur. Madde faktör yükleri .45 ile .68 arasındadır. Modele ilişkin uyum indeksleri incelendiğinde $\mathrm{RMSEA}=.06, \mathrm{SRMR}=.05, \mathrm{NFI}=.93, \mathrm{CFI}=.96, \mathrm{RFI}=.93$ ve $\mathrm{IFI}=.96$ olarak bulunmuştur (Telef, 2014).

\section{Verilerin Toplanması, Hazırlanması veAnalizi}

Araştırmada kullanılan veri toplama araçları araştırmacılar tarafından bir araya getirilerek 2015-2016 eğitimöğretim yılının bahar döneminde ortaokul öğrencilerine sınıflarında, bir ders saati içerisinde gerekli açıklamalar yapıldıktan sonra uygulanmıştır. Verilerin analizi aşamasına geçilmeden önce veriler analiz için hazırlanmıştır. Bunun için öncelikle kayıp değerler incelenmiştir. Kayıp veri oranı eğitim stresi ölçeği için 1 (\% 0.5), okul yaşam kalitesi ölçeği için 1 (\% 0.5), okul çocuklarının mutluluk envanteri için 19 (\%4.47)'dur. 
Kayıp veri oranı \%5'in altında olduğu için kabul edilebilir düzeydedir (Tabachnick ve Fidell, 2007). Dolayısıyla kayıp veriler için seriler ortalaması atama yöntemi kullanılmıştır. Verilerin analize hazırlık aşamasında tek yönlü ve çok yönlü uç değerler incelenmiştir. Tek yönlü uç değerlerin incelenmesinde standardize edilmiş $\mathrm{z}$ puanlarına bakılmıştır. $\mathrm{Z}$ puan aralığının -3 ve +3 puan aralığında olması gerekmektedir (Çokluk, Şekercioğlu ve Büyüköztürk, 2014). Standardize edilmiş z puanlarında -3 ve +3 puan aralığı dışında kalan 13 gözlem veri setinden çıkarılmıştır. Çok değişkenli uç değerlerin incelenmesinde ise Mahalanobis uzaklık değerleri incelenmiştir. $\alpha=.001$ manidarlık düzeyi 10 serbestlik derecesinde $\chi^{2}=29.588$ değerini aşan1 uç değere rastlanmış ve veri setinden çıkarılmıştır. Bu araştırmada eğitim stresi ve okul yaşam kalitesininortaokul öğrencilerinin mutluluklarını yordama durum ve düzeyini incelemek için çoklu doğrusal regresyon analiz yöntemininkullanılmasına karar verilmiştir. Çoklu doğrusal regresyon analizi en az aralık ölçeğinde ölçülen sürekli değişkenleri gerektirir. Ayrıca çoklu doğrusal regresyon analizi için değişkenler tek değişkenli ve çok değişkenli normal dağılım göstermeli, yordayıcı değişkenlerle bağımlı değişken arasında doğrusal bir ilişki olmalı, yordayıcı değişkenler arasında çoklubağlantılılık sorunu olmamalıdır (Büyüköztürk, 2012). Analizlere geçilmeden önce belirtilen çoklu doğrusal regresyon analizi varsayımları sırasıyla incelenmiştir. Analizler için SPSS 22 paket programı kullanılmıştır.Tek değişkenli normallik dağılımının incelenmesi için ortalama, ortanca, mod değerleri ilebasıklık ve çarpıklık katsayıları incelemesi yapılmıştır. Eğitim stresi ölçeği çalışma baskısı, ders yükü, başarı kaygısı, beklenti ve umutsuzluk alt boyutları, okul yaşam kalitesi ölçeği öğretmenler, öğrenciler, okula yönelik duygular, okul yönetimi, statü alt boyutları ve okul çocuklarının mutluluk puanlarına ilişkin olarak ortalama, ortanca, mod değerleri ile çarpıklık ve basıklık katsayıları Tablo-1'de gösterilmiştir.

Tablo 1. Bă̆ımlı ve Bă̆ımsız Değişken Puanlarına İlişkin Ortalama-Ortanca-Değerleri ve ÇarpıklıkBasıklık Katsayıları

\begin{tabular}{llccccc} 
Değişkenler & \multicolumn{1}{c}{ Alt Boyutlar } & Ortalama & Ortanca & Mod & Çarpıklık & Basıklık \\
\hline \multirow{3}{*}{$\begin{array}{l}\text { Eğitim } \\
\text { Stresi }\end{array}$} & Çalışma Baskısı & 9.38 & 9.00 & 7.00 & .443 & -.304 \\
\cline { 2 - 7 } & Ders Yükü & 7.09 & 7.00 & 6.00 & .558 & -.209 \\
\cline { 2 - 7 } & Başarı Kaygısı & 15.73 & 16.00 & 16.00 & -.579 & -.266 \\
\cline { 2 - 7 } & $\begin{array}{l}\text { Beklenti ve } \\
\text { Umutsuzluk }\end{array}$ & 16.45 & 16.00 & 15.00 & -.026 & -.200 \\
\hline \multirow{3}{*}{$\begin{array}{l}\text { Okul } \\
\text { Kaşam }\end{array}$} & Öğretmenler & 35.21 & 36 & $43-.455$ & & -.561 \\
\cline { 2 - 7 } & Öğrenciles & 22.44 & 22 & 19 & .160 & -.557 \\
\cline { 2 - 7 } & $\begin{array}{l}\text { Okula Yönelik } \\
\text { Duygular }\end{array}$ & 28.79 & 30.00 & 40.00 & -.500 & -.406 \\
\cline { 2 - 7 } & Okul Yönetimi & 22.67 & 23.00 & 23.00 & -.074 & -.754 \\
\cline { 2 - 7 } & Statü & 11.40 & 12.00 & 15.00 & -.815 & -.053 \\
\hline Okul Çocuklanı & 92.04 & 93.11 & 103.00 & -.529 & -.166 \\
\hline
\end{tabular}

Tüm değişken verileri için ortalama, ortanca ve mod değerlerinin birbirine yakın olduğu,basıklık ve çarpıklık katsayısının +1 ve -1 aralığında kaldığı gözlenmiştir.Yapılan incelemeler sonucunda eğitim stresi ölçeği çalışma baskısı, ders yükü, başarı kaygısı, beklenti ve umutsuzluk alt boyutları, okul yaşam kalitesi ölçeği öğretmenler, öğrenciler, okula yönelik duygular, okul yönetimi, statü alt boyutları ve okul çocuklarının 
mutluluk puanlarının normal dağılım gösterdiğine karar verilmiştir. Verilerin çok değişkenli normal dağılımdan geldiği Bartlett Küresellik Testi ile ortaya konabilir (Çokluk, Şekercioğlu ve Büyüköztürk, 2014). Barlettt testi sonucuna göre ki-kare istatistiği manidar bulunmuştur $\left(X^{2}=847.08, \mathrm{p}<.01\right)$. Buna göre verilerin çok değişkenli normal dağılımdan geldiği kabul edilmiştir. Çok değişkenli normallik sayıltısı değişken çiftleri arasındaki ilişkinin doğrusal olduğuna işaret etmektedir (Çokluk, Şekercioğlu ve Büyüköztürk, 2014). Dolayısıyla doğrusallık varsayımının sağlandığı kabul edilmiştir. Yordayıcı değişkenlerin kendi aralarında çoklu bağlantılılık sorunu olup olmadığına yordayıcı değişkenler arası korelasyon değerleri, tolerans değerleri ve varyans büyütme faktör (VIF) değerleri incelenerek karar verilebilir (Can, 2014). Çoklu bağlantılılık sorunu incelemesi için modele dahil edilen yordayıcı değişkelere ait korelasyon değerleri, tolerans değeri, ve varyans büyütme faktörü (VIF) değerleri Tablo 2'de verilmiştir.

Tablo2.Modele İlişkin Korelasyon ve Çoklu Bağlantılılık Testi Tablosu

\begin{tabular}{|c|c|c|c|c|c|c|c|}
\hline \multirow{2}{*}{$\begin{array}{l}\text { Model } \\
1\end{array}$} & \multirow{2}{*}{$\begin{array}{l}\text { Yordayıcı } \\
\text { Değikenler }\end{array}$} & \multirow[b]{2}{*}{ Alt Boyutlar } & \multicolumn{3}{|c|}{ Korelasyonlar } & $\begin{array}{l}\text { Çoklu } \\
\text { İstatistikleri }\end{array}$ & Bağlantılılık \\
\hline & & & $\begin{array}{l}\text { Sifir } \\
\text { Düzey }\end{array}$ & K1smi & $\begin{array}{l}\text { Yar1 } \\
\text { Kismi }\end{array}$ & Tolerans & VIF \\
\hline & \multirow{4}{*}{ Eğitim Stresi } & Çalışma Baskısı & -.384 & -.204 & -.172 & .747 & 1.338 \\
\hline & & Ders Yükü & -.291 & -.092 & -.076 & .774 & 1.291 \\
\hline & & Başarı Kaygısı & -.112 & -.024 & -.020 & .825 & 1.213 \\
\hline & & $\begin{array}{l}\text { Beklenti ve } \\
\text { Umutsuzluk }\end{array}$ & -.314 & -.154 & -.129 & .734 & 1.362 \\
\hline & \multirow{5}{*}{$\begin{array}{l}\text { Okul } \\
\text { Yaşam Kalitesi }\end{array}$} & Öğretmenler & .348 & .088 & .073 & .612 & 1.633 \\
\hline & & Öğrenciler & .178 & .054 & .045 & .882 & 1.678 \\
\hline & & $\begin{array}{l}\text { Okula Yönelik } \\
\text { Duygular }\end{array}$ & .378 & .110 & .091 & .596 & 1.511 \\
\hline & & Okul Yönetimi & .310 & .075 & .062 & .662 & 1.298 \\
\hline & & Statü & .344 & .187 & .157 & .770 & \\
\hline
\end{tabular}

Bağımlı değişken mutluluk

Korelasyon değerlerinin .80 üzerinde olması çoklu bağlantılılık sorununa işaret etmektedir (Büyüköztürk, 2012). Modeldeki korelasyon değerleri incelendiğinde yordayıcı değişkenlerin çoklu bağlantılılık sorunu taşımadığı söylenebilir. Tolerans değerlerinin.20'den büyük olması tolerans değerleri açısından çoklu bağlantılılık sorunu olmadığını, VIF değerlerinin 5'den küçük olması VIF değerleri açısından da çoklu bağlantılılık sorunu olmadığını göstermektedir (Büyüköztürk, 2012). Tablo-2 incelendiğinde yordayıc1 değişkenler arasında çoklubağlantılılık sorunu olmadığı sonucuna ulaşılmıştır.

Çoklu regresyon analizi temel varsayımlarının incelenmesi sonucunda varsayımların karşılanmış olduğuna karar verilmiştir. Bu nedenle eğitim stresi ve okul yaşam kalitesinin ortaokul öğrencilerinin mutluluklarını manidar şekilde yordama durumlarını ve düzeylerini incelemek amacıyla çoklu regresyon analizi yapılması 
uygun bulunmuştur. Çoklu regresyon analiz yöntemlerinden ise aşamalı regresyon analizi yöntemi kullanılmıştır. Aşamalı regresyon yönteminde her değişken modele bağımlı değişkenin varyansına en çok katk1 yapma sırasına bağlı olarak eklenir ve değerlendirilir. Eğer eklenen değişken modele anlamlı katk1 sağlıyorsa bu değişkenmodelde kalır, eğer modele önemli bir katkı sağlamıyorsa modelden çıkarılır (Kalayc1, 2014).

\section{Bulgular}

Eğitim stresi ölçeği alt boyutları çalışma baskısı, ders yükü, başarı kaygısı, beklenti ve umutsuzluk alt boyut puanlarına, Okul yaşam kalitesi ölçeği öğretmenler, öğrenciler, okula yönelik duygular, okul yönetimi, statü alt boyut puanlarına ve okul çocukları mutluluk envanteri puanlarına ilişkin betimsel istatistikler Tablo-3'te verilmiştir.

Tablo 3.Yordanan ve Yordayıcı Değişkenlere İlişkin Betimsel İstatistikler

\begin{tabular}{|c|c|c|c|c|c|c|}
\hline Değişkenler & Alt Boyutlar & $\mathrm{N}$ & $\bar{X}$ & $\sigma$ & $\begin{array}{l}\text { Maksimum } \\
\text { Değer }\end{array}$ & $\begin{array}{l}\text { Minimum } \\
\text { Değer }\end{array}$ \\
\hline \multirow{4}{*}{ Eğitim Stresi } & Çalışma Baskısı & 411 & 9.38 & 3.31 & 19 & 4 \\
\hline & Ders Yükü & 411 & 7.09 & 2.84 & 15 & 3 \\
\hline & Başarı Kaygısı & 411 & 15.73 & 3.00 & 20 & 7 \\
\hline & $\begin{array}{l}\text { Beklenti ve } \\
\text { Umutsuzluk }\end{array}$ & 411 & 16.45 & 3.97 & 25 & 5 \\
\hline \multirow{5}{*}{$\begin{array}{l}\text { Okul Yaşam } \\
\text { Kalitesi }\end{array}$} & Öğretmenler & 411 & 35.21 & 6.78 & 45 & 14 \\
\hline & Öğrenciler & 411 & 22.44 & 7.48 & 43 & 9 \\
\hline & $\begin{array}{l}\text { Okula Yönelik } \\
\text { Duygular }\end{array}$ & 411 & 28.79 & 7.71 & 40 & 8 \\
\hline & Okul Yönetimi & 411 & 22.67 & 6.91 & 35 & 7 \\
\hline & Statü & 411 & 11.40 & 3.19 & 15 & 3 \\
\hline \multicolumn{2}{|c|}{$\begin{array}{l}\text { Ortaokul Öğrencilerinin } \\
\text { Mutluluk Düzeyi }\end{array}$} & 411 & 92.04 & 15.67 & 120 & 44 \\
\hline
\end{tabular}

Tablo-3'e göre eğitim stresi ölçeği alt boyutları çalışma baskısı ortalaması $\bar{X}=9.38(\sigma=3.31)$, ders yükü ortalamas $\bar{X}=7.09(\sigma=2.84)$, başarı kaygısı ortalaması $\bar{X}=15.73(\sigma=3.0)$, beklenti ve umutsuzluk kaygısı ortalamas $\bar{X}=16.45(\sigma=3.97)$, okul yaşam kalitesi ölçeği alt boyutları öğretmenler ortalaması $\bar{X}=35.21$ ( $\sigma=6.78)$, öğrenciler ortalamas $1 \bar{X}=22.44(\sigma=7.48)$, okula yönelik duygular ortalamas $\bar{X}=28.79(\sigma$ $=7.71)$, okul yönetimi ortalaması $\bar{X}=22.67(\sigma=6.91)$, statü ortalaması $\bar{X}=11.40(\sigma=3.19)$ ve okul çocukları mutluluk düzeyi ortalaması $\bar{X}=92.04(\sigma=15.67)^{\prime}$ dir.

Eğitim stresi (çalışma baskısı, ders yükü, başarı kaygısı, beklenti ve umutsuzluk) ve okul yaşam kalitesinin (öğretmenler, öğrenciler, okula yönelik duygular, okul yönetimi, statü)ortaokul öğrencilerinin mutluluk düzeylerini manidar düzeyde yordayıp yordamadığını belirlemek amacıyla kurulan regresyon modeli Tablo4'de sunulmuştur. 
Tablo 4.Regresyon Model Özeti

\begin{tabular}{ccccc}
\hline Model & $\mathrm{R}$ & $\mathrm{R}^{2}$ & Düzeltilmiş $\mathrm{R}^{2}$ & Kestirimin Standart Hatası \\
\hline 1 & $.384^{\mathrm{a}}$ & .148 & .146 & 14.49 \\
\hline 2 & $.487^{\mathrm{b}}$ & .238 & .234 & 13.72 \\
\hline 3 & $.524^{\mathrm{c}}$ & .275 & .270 & 13.39 \\
\hline 4 & $.545^{\mathrm{d}}$ & .297 & .290 & 13.20 \\
\hline 5 & $.555^{\mathrm{e}}$ & .308 & .320 & 13.11 \\
\hline
\end{tabular}

Bağımlı değişken: Mutluluk

a.Yordayıcılar: ESÖ Çalışma Baskısı

b. Yordayıcılar: ESÖ Çalışma Baskısı, OYKÖ Statü

c.Yordayıcılar: ESÖ Çalışma Baskısı, OYKÖ Statü, OYKÖ Okula Yönelik Duygular

d.Yordayıcılar:ESÖ Çalışma Baskısı, OYKÖ Statü, OYKÖ Okula Yönelik Duygular, ESÖ Beklentiye Karş1 Umutsuzluk

e.Yordayıcılar: ESÖ Çalışma Baskısı, OYKÖ Statü, OYKÖ Okula Yönelik Duygular, ESÖ Beklentiye Karşı Umutsuzluk, OYKÖ Öğretmen

Tablo 4'de görüldüğü gibi birinci modelde eğitim stresi ölçeği alt boyutu olan çalışma baskısı ortaokul öğrencilerinin mutluluk düzeylerinin \%15'ini açıklamaktadır. İkinci modelde eğitim stresi ölçeği alt boyutu olan çalışma baskısı ve okul yaşam kalitesi ölçeğinin statü alt boyutu birlikte ortaokul öğrencilerinin mutluluk düzeylerinin \%24'ünü açıklamaktadır. Üçüncü modelde eğitim stresi ölçeği alt boyutu olan çalışma baskısı, okul yaşam kalitesi ölçeğinin statü alt boyutu ve okula yönelik duygular alt boyutu birlikte ortaokul öğrencilerinin mutluluk düzeylerinin \%27'sini açıklamaktadır. Dördüncü modelde eğitim stresi ölçeği alt boyutu olan çalışma baskısı, okul yaşam kalitesi ölçeğinin statü alt boyutu ve okula yönelik duygular alt boyutu ve eğitim stresi ölçeğinin beklentiye karşı umutsuzluk alt boyutu birlikte ortaokul öğrencilerinin mutluluk düzeylerinin \%30'unuaçıklamaktadır. Beşinci modelde eğitim stresi ölçeği alt boyutu olan çalışma baskısı, okul yaşam kalitesi ölçeğinin statü alt boyutu ve okula yönelik duygular alt boyutu ve eğitim stresi ölçeğinin beklentiye karşı umutsuzluk alt boyutu ve okul yaşam kalitesi ölçeğinin öğretmen alt boyutu birlikte ortaokul öğrencilerinin mutluluk düzeylerinin \%31'ini açıklamaktadır. Buna göre beş değişkenle daha fazla varyans açıklandığı için beşinci model temel alınarak analizlere devam edilmiştir.

Eğitim stresi ölçeği alt boyutu olan çalışma baskısı, okul yaşam kalitesi ölçeği alt boyutu olan statü ve okula yönelik duygular, eğitim stresi ölçeğinin beklentiye karşı umutsuzluk alt boyutu ve okul yaşam kalitesi ölçeğinin öğretmen alt boyutu birlikte ortaokul öğrencilerinin mutluluk düzeylerini manidar bir şekilde yordayıp yordamadığını belirlemek amacıyla kurulan regresyon modelindeki R'nin manidarlığını test eden ANOVA testi sonucu Tablo-5' de sunulmuştur. 
Tablo 5.Regresyon Modelinin ANOVAAnalizi

\begin{tabular}{clccccc}
\hline & Model & Kareler Toplam1 & sd & Kareler Ortalamas1 & F & P \\
\hline \multirow{2}{*}{5} & Regresyon & 31030.35 & 5 & 6206.07 & 36.09 & .000 \\
& Artık değerler & 69640.01 & 405 & 171.95 & & \\
& Toplam & 100670.37 & 410 & & & \\
\hline
\end{tabular}

Bağımlı değişken: Mutluluk

Yordayıcılar: ESÖ Çalışma Baskısı, OYKÖ Statü, OYKÖ Okula Yönelik Duygular, ESÖ Beklentiye Karş1 Umutsuzluk, OYKÖ Öğretmen

Tablo 5 incelendiğinde regresyon modelinin anlamlılığını test eden ANOVA testi sonucundaki p değeri .01 'den küçük olduğu için $(\mathrm{p}=.000)$, yordanan değişkenlerle yordayıcı değişkenler arasındaki ilişki .01 düzeyinde manidardır.

Eğitim stresi ölçeği alt boyutu olan çalışma baskısı, okul yaşam kalitesi ölçeği alt boyutu olan statü ve okula yönelik duygular, eğitim stresi ölçeğinin beklentiye karşı umutsuzluk alt boyutu ve okul yaşam kalitesi ölçeğinin öğretmen alt boyutu birlikte ortaokul öğrencilerinin mutluluk düzeylerini yordamasına ilişkin regresyon analizi sonucu Tablo 6'da verilmiştir.

Tablo 6.Regresyon Modeli Analiz Sonuçları

\begin{tabular}{|c|c|c|c|c|c|c|c|}
\hline \multirow[t]{2}{*}{ Model } & \multicolumn{2}{|c|}{$\begin{array}{l}\text { Standartlaştırılmamış } \\
\text { Katsayılar }\end{array}$} & \multirow{2}{*}{$\begin{array}{c}\begin{array}{c}\text { Standartlaştırıl-mış } \\
\text { Katsayılar }\end{array} \\
\text { B } \\
\end{array}$} & \multirow[t]{2}{*}{$\mathrm{t}$} & \multirow[t]{2}{*}{$\mathrm{p}$} & \multirow[t]{2}{*}{ İkili r } & \multirow{2}{*}{$\begin{array}{c}\text { Kismi } \\
\mathrm{r}\end{array}$} \\
\hline & $\mathrm{B}$ & Std. Hata & & & & & \\
\hline (Sabit) & 83.641 & 5.275 & & 15.86 & .000 & & \\
\hline $\begin{array}{c}\text { ESÖ-Çalışma } \\
\text { Baskısı }\end{array}$ & -1.12 & .215 & -.237 & -.5 .20 & .000 & -.384 & -.250 \\
\hline OYK-Statü & .866 & .228 & .176 & 3.79 & .000 & .344 & .185 \\
\hline $\begin{array}{c}\text { OYK-Okula Yönelik } \\
\text { Duygular }\end{array}$ & .323 & . 102 & .159 & 3.16 & .002 & .378 & .155 \\
\hline $\begin{array}{c}\text { ESÖ-Beklentiye } \\
\text { Karş1 Umutsuzluk }\end{array}$ & -.651 & .176 & -.165 & -3.71 & .000 & -.314 & -.181 \\
\hline OYK-Öğretmen & .296 & .115 & .128 & 2.58 & .010 & .348 & .127 \\
\hline $\begin{array}{l}\mathrm{R}=.555 \mathrm{R}^{2}=.308 \\
\mathrm{~F}(5,405)=36.092\end{array}$ & & & & & & & \\
\hline
\end{tabular}

Tablo 6'ya göre çocukların mutluluk düzeyleri üzerinde etkisi olduğu düşünülen eğitim stresi (çalışma baskıs1, ders yükü, başarı kaygısı, beklentiye karşı umutsuzluk) ve okul yaşam kalitesi (öğretmen, öğrenci, okula yönelik duygular, okul yönetimi, statü) değişkenlerine yönelik olarak yapılan çoklu regresyon yöntemlerinden aşamalı regresyon analizi sonucunda modele dahil edilen beş değiş̧ken (çalışma baskısı, statü, okula yönelik duygular, beklentiye karşı umutsuzluk, öğretmen) birlikte ortaokul öğrencilerinin mutluluk düzeyleri ile orta düzeyde anlamlı bir ilişki vermektedir $\left[R=0.555, \mathrm{~F}_{(5,405)}=36.092\right.$, $\left.\mathrm{p}=.000\right]$. Eğitim stresi ölçeği çalışma baskısı alt boyutu B çalşmabaskıı =-1.12'dir. Başka bir ifade ile çalışma baskısı alt boyutu 
puanlarındaki bir birimlik artış, ortaokul öğrencilerininmutluluk düzeylerindeki 1.12 birimlik bir azalışa neden olmaktadır. Okul yaşam kalitesi ölçeği statü alt boyutu $\mathrm{B}$ statü=.87'dir. Başka bir ifade ile statü alt boyutu puanlarındaki bir birimlik artış, ortaokul öğrencilerinin mutluluk düzeylerindeki .87 birimlik bir artışa neden olmaktadır. Okul yaşam kalitesi ölçeği okula yönelik duygular alt boyutu B okulayönelikduygular=.32'dir. Başka bir ifade ileokula yönelik duygular alt boyutu puanlarındaki bir birimlik artış, ortaokul öğrencilerinin mutluluk düzeylerindeki .32 birimlik bir artışa neden olmaktadır. Eğitim stresi ölçeği beklentiye karş1 umutsuzluk alt boyutu $\mathrm{B}$ beklentiyekarşıumutsuzluk=-.65'dir. Başka bir ifade ile beklentiye karş1 umutsuzluk alt boyutu puanlarındaki bir birimlik artış, ortaokul öğrencilerinin mutluluk düzeylerindeki .65birimlik bir azalmaya neden olmaktadır. Okul yaşam kalitesi ölçeği öğretmenler alt boyutu B ögretmenler $=.30$ 'dur. Dolayısıyla öğretmen alt boyut puanlarındaki bir birimlik artış, ortaokul öğrencilerinin mutluluk düzeylerindeki .30 birimlik bir artışa neden olmaktadır.Çoklu doğrusal regresyon analizinde, farklı ölçme birimleri ve varyanslara sahip bağımsız değişkenlerin bağımlı değişkene ilişkin göreli önem sıralarını yorumlamada standardize edilmiş regresyon katsayıları olan $\beta$ (beta) değerlerine, işaretlerine dikkat etmeksizin bakılmaktadır. En yüksek beta değerine sahip olan değişken göreli olarak en önemli yordayıcıdır (Büyüköztürk, 2012). Tablo 6'da verilen standartlaştırılmış regresyon katsayılarına göre, yordayıcı değişkenlerin, ortaokul öğrencilerinin mutluluk düzeyleri üzerindeki göreli önem sırası; çalışma baskısı( $\beta=-$ .237), statü ( $\beta=.176)$, beklentiye karşı umutsuzluk ( $\beta=-.165)$, okula yönelik duygular ( $\beta=. .159)$, öğretmen $(\beta=.128)$ şeklindedir. Regresyon katsayılarının anlamlılığa ilişkin t-testi sonuçları incelendiğinde yordayıcı tüm değişkenler içerisinde, çalışma baskısı ( $\mathrm{t}=-5.20, \mathrm{p}=.000)$,statü $(\mathrm{t}=3.79, \mathrm{p}=.000)$, okula yönelik duygular $(\mathrm{t}=3.16, \mathrm{p}=.002)$, beklentiye karş1 umutsuzluk $(\mathrm{t}=-3.71, \mathrm{p}=.000)$, öğretmen'in $(\mathrm{t}=2.58, \mathrm{p}=.010)$ ortaokul öğrencilerinin mutluluk düzeyleri üzerinde manidar yordayıcılar oldukları görülmektedir. Yordayıcı değişkenlerle ortaokul öğrencilerinin mutluluk düzeyleri arasındaki ikili ve kısmi korelasyonlara bakıldığında çalışma baskısı ile mutluluk düzeyi arasındaki korelasyonun ( $\mathrm{r}=-.384)$, diğer yordayıcı değişkenlerin etkisi kontrol edildiğinde ise ( $\mathrm{r}=-$.250) olduğu, statü ile mutluluk düzeyi arasındaki korelasyonun ( $\mathrm{r}=.344)$, diğer yordayıcı değişkenlerin etkisi kontrol edildiğinde ise ( $\mathrm{r}=.185)$ olduğu, okula yönelik duygular ile mutluluk düzeyi arasındaki korelasyonun $(r=.378)$, diğer yordayıcı değişkenlerin etkisi kontrol edildiğinde ise $(\mathrm{r}=.155)$ olduğu, beklentiye karşı umutsuzluk ile mutluluk düzeyi arasındaki korelasyonun ( $\mathrm{r}=-.314)$, diğer yordayıcı değişkenlerin etkisi kontrol edildiğinde ise ( $\mathrm{r}=-.181)$ olduğu, öğretmen ile mutluluk düzeyi arasındaki korelasyonun $(\mathrm{r}=.348)$, diğer yordayıcı değişkenlerin etkisi kontrol edildiğinde ise ( $\mathrm{r}=.127)$ olduğu görülmektedir. Buna göre ortaokul öğrencilerinin mutluluk düzeyleri ile eğitim stresi ölçeği alt boyutlarından çalışma baskısı ve beklentiye karşı umutsuzluk arasında negatif yönde ve orta düzeyde bir ilişki bulunmaktadır. Bununla birlikte ortaokul öğrencilerinin mutluluk düzeyleri ile okul yaşam kalitesi ölçeği statü, okula yönelik duygular, öğretmen alt boyutları arasında pozitif yönde ve orta düzeyde anlamlı bir ilişki bulunmaktadır.

Regresyon analizi sonuçlarına göre, ortaokul öğrencilerinin mutluluk düzeylerini (OÇMD) yordayan regresyon denklemi şu şekildedir: 
$O C ̧ M D=83.641+(0.866 \times$ Statü +0.323 x Okula Yönelik Duygular +0.296 x Öğretmen $)-(1.12 \times$ Çalışma Baskısı + 0.651 x Beklentiye Karşı Umutsuzluk).

\section{Tartışma}

$\mathrm{Bu}$ araştırma eğitim stresi ve okul yaşam kalitesinin ortaokul öğrencilerinin okul ortamındaki mutluluklarını manidar şekilde yordayıp yordamadığını incelemek amacıyla yapılmıştır. Eğitim stresi çalışma baskısı, ders yükü, başarı kaygısı, beklenti ve umutsuzluk boyutlarıyla, okul yaşam kalitesi ise öğretmenler, öğrenciler, okula yönelik duygular, okul yönetimi ve statü boyutlarıyla ölçülmüştür.Öğretmenler boyutu, öğretmenlerin öğrencilerle olan iletişimlerinin niteliği ve mesleki anlamda kendini geliştirme düzeyleriyle, öğrenciler boyutu daha çok öğrencilerin birbirleriyle iletişimlerinin niteliğiyle ilgilidir.Okula yönelik duygular boyutu ise okula yönelik hem olumlu hem de olumsuz duyguları içermektedir. Okul yönetimi boyutu okul yöneticilerinin öğrencilerle olan iletişimlerinin niteliğiyle, okulda öğrencilerin sorunlarına yönelik duyarlılık düzeyleriyle, statü boyutuise okulda öğrencilerin birbirleriyle ilgili olarak kendilerini ne düzeyde önemli ve değerli hissettikleri ile ilgilidir.

Eğitim stresi ve okul yaşam kalitesi boyutlarının ortaokul öğrencilerinin mutluluk düzeylerini yordayıp yordamadığını belirlemek amacıyla kurulan regresyon modeline göre modele dahil edilen çalışma baskısı, statü, okula yönelik duygular, beklentiye karşı umutsuzluk, öğretmen değişkenleri birlikte ortaokul öğrencilerinin mutluluk düzeylerinin \%31'ini açıklamaktadır. Beş değişkenle en fazla varyans açıklandığı için bu model araştırmada temel alınmıştır. Sonuç olarak, modele dahil edilen çalışma baskısı, statü, okula yönelik duygular, beklentiye karşı umutsuzluk, öğretmen boyutları birlikte ortaokul öğrencilerinin mutluluk düzeylerini 0.01 anlamlılık düzeyinde manidar bir şekilde yordamaktadır. Bu modele göre ortaokul öğrencilerinin mutluluk düzeylerinin manidar yordayıcılarının göreli olarak önem sırasıçalışma baskısı, statü, okula yönelik duygular, beklentiye karşı umutsuzluk, öğretmen boyutlardır. Modele dahil edilen bu beş değişken ile (çalışma baskısı, statü, okula yönelik duygular, beklentiye karşı umutsuzluk, öğretmen) birlikte ortaokul öğrencilerinin mutluluk düzeyleri orta düzeyde anlamlı bir ilişki vermektedir.

Ortaokul öğrencilerinin mutluluk düzeyleri ile eğitim stresi boyutlarından sırasıyla çalışma baskısı ve beklentiye karşı umutsuzluk arasında negatif yönde ve orta düzeyde bir ilişki bulunmaktadır. Başka bir ifade ile öğrenciler üzerindeki çalışma baskısının fazla olması, ailelerin yüksek beklentileri ve öğrencilerin başarılı olamayacaklarına ilişkin umutsuzlukları ortaokul öğrencilerini mutsuzlaştırmaktadır. Çalışma baskısı ve beklentiye karşı umutsuzluk birer eğitim stresi kaynağıdır. Dolayısıyla eğitim stresinin artması sonucunda ortaokul öğrencilerinin daha mutsuz olduğu söylenebilir. Natvig, Alberktson ve Ovarnstom (2003) 1017 (1315yaş) Norveçli öğrenciyle okul temelli mutlulukla ilgili anket çalışmaları yapmışlardır. Araştırmacılar çalışmalarının sonucunda stres düzeyi yüksek olan öğrencilerin mutluluk düzeylerinin düşük olduğunu rapor etmişlerdir. Bununla birlikte 485 üniversite öğrencisi ile yapılan farklı bir araştırmada da benzer bir sonuca ulaşılmıştır. Düşük seviyede mutluluk algısı olduğu belirlenen öğrencilerin stres seviyeleri daha yüksek 
bulunmuştur (King, Vidourek, Merianos ve Singh, 2014). Eğitim stresinin kaynaklarından çalışma baskısı ve beklentiye karşı umutsuzluk boyutları ortaokul öğrencilerinin mutluluk düzeylerinin anlamlı yordayıcılarıyken, başarı kaygısı ve ders yükü mutluluk düzeyinin anlamlı yordayıcıları değildir. Başarı kaygısı ve ders yükünün ortaokul öğrencilerinin mutluluk düzeylerinin anlamlı yordayıcıları olarak modele dahil edilmemiş olmamasının çeşitli nedenleri olabilir. Başarı kaygısının ortaokul öğrencilerinin mutluluk düzeyini yordayan değişkenleri içeren modele katkı sağlamamasının bir nedeni öğrencilerin belli bir düzeyde kaygı yaşamalarının doğal ve sağlıklı bir durum olması olabilir.Kaygı duygusunun tehdit veya tehlikeye karşı verilen doğal bir tepki olduğu bilinmektedir. Ders yükü ile ilgili olarak ise eğitim sistemimiz içerisindeki öğrencilerin, eğitim-öğrenim hayatlarının ilk yıllarından başlayarak haftalık ders saat yüklerinin fazla olması, ev ödevlerinin yoğun olması öğrencilerin ders yükü algılarını değiştirmiş ve normalleştirmiş olabilir.Bunun içinde ders yükü mutluluk düzeylerini yordayan manidar bir değişken olarak modele dahil edilmemiş olabilir.

Yapılan araştırma sonuçlarına göreortaokul öğrencilerinin mutluluk düzeyleri ile okul yaşam kalitesi ölçeği sırasıyla statü, okula yönelik duygular, öğretmen boyutları arasında pozitif yönde ve orta düzeyde anlamlı bir ilişki bulunmaktadır.Okul ortamında kendini önemli ve değerli hisseden, okula yönelik olumlu duyguları olan, öğretmenleriyle iyi ilişkileri olan öğrencilerin okul ortamında daha mutlu oldukları söylenebilir. Ortaokul öğrencilerinin mutluluk düzeylerinin önem sırasına göre ikinci önemli yordayıcısılan statü boyutu öğrencilerin kendilerini ne düzeyde önemli ve değerli hissettikleri ile ilgilidir. Bireyin kendini yeterli, değerli ve önemli hissetmesi Doğan ve Eryılmaz (2013)'ın Coopersmith (1967)'den aktardığı şekli ile benlik saygısı olarak kavramsallaştırılmıştır. Yapılan araştırmalarda mutluluk düzeyi ile benlik saygısı arasında pozitif yönde anlamlı düzeyde ilişki olduğuve benlik saygısının mutluluğun bir yordayıcısı olduğu sonucuna varılmıştır (Çevik, 2010; Doğan ve Eryılmaz, 2013; Karatzias, Chouliara, Power ve Swanson, 2006). Ayrıca dokuz alan çalışmasının incelendiği ve öznel iyi oluşla 137 kişilik özelliğinin ilişkisini inceleyen araştırma sonuçlarına göre de öznel iyi oluşla benlik saygısı arasında güçlü bir ilişki bulunmaktadır (DeNeve ve Cooper, 1998). Çocukların okuldaki mutluluğu için önemli rol oynayan bir diğer etken ise olumlu ve destekleyici okul iklimidir (McCabe, Bray, Kehle, Theodore ve Gelbar, 2011). Çocukların okula karşı tutumları ve duyguları okula yönelik duygular boyutu altında incelenmiştir. Bugüne kadar yapılan pek çok araştırma okula yönelik tutumların okul başarısı ile ilişkili olduğunu ortaya koymuştur (Adıgüzel, 2012; Cheng ve Chan, 2003, Erkman, Caner, Sart, Börkan ve Şahan, 2010). Ancak yapılan bu araştırmada ile okula yönelik duyguların akademik başarı dışında çocukların okul ortamında iyi oluşlarıyla da ilişki olduğu sonucuna ulaşılmıştır. Okulun öğrenciler üzerindeki akademik, sosyal ve psikolojik çıktıları üzerindeki önemli etkileri nedeniyleöğrencilerin okullarını sevmeleri ve okuldaki deneyimlerinden doyum sağlamaları giderek daha fazla önem kazanan konulardan biri haline gelmektedir. Öğrencilerin okullarında geçirdikleri yaşantıların şekillenmesinde özellikle öğretmenler önemli bir rol oynamaktadır (Sarı, 2012b). Öğretmenler, öğrencilerin dersi sevmesinde, çalışma alışkanlığ kazanmasında, kişiliğinin gelişiminde, benimseyeceği değer yargı ve tutumlarında, öğrencinin kendini gerçekleştirmesinde büyük bir rol oynarlar (Yavuzer, 2011). 
Yapılanbu araştırmanın sonuçlarıda öğretmenin öğrencinin okulda mutlu olmalarında rol oynadığını göstermektedir. Natvig, Albrektsen ve Qvarnstørm (2003) yaptıkları araştırmada öğretmenlerden ve akranlardan gelen sosyal desteğin öğrencilerin mutluluklarını anlamlı düzeyde artırdığını rapor etmişlerdir. Hem öğretmen hem de akran desteği öğrencilerin mutluluk düzeyi ile pozitif yönde anlamlı ilişkili olmasına rağmen, öğretmen desteği akran desteğine göre daha önemli bulunmuştur. Yapılan bu araştırmanın sonuçlarına göre de öğrenci-öğrenci ilişkileri ortaokul öğrencilerinin mutluluk düzeylerinin açıklandığı modele anlamlı katkı sunmamıştır. Ayrıca bu araştırmanın sonuçlarına göre okul yönetiminin de ortaokul öğrencilerinin mutluluk düzeylerinin açıklandığı modele anlamlı katkı sunmadığı görülmüştür. Okul yönetiminin modele anlamlı katkı sunmamasının nedenihiyerarşik ilişkilerin baskın olduğu okul ortamında okul yönetiminin öğrencilere yakın olmayan ilişki biçiminin öğrenciler tarafından benimsenmiş ve kabul edilmiş olması olabilir. Ancak yapılan araştırmalar ortaokul öğrencilerinin mutlulukları ile sırasıyla arkadaş ilişkilerinin ve okul yönetiminin ilişkili olduğunu göstermektedir (Sarı, 2012b;Çevik, 2010;Döş, 2013).

Birleşmiş Milletler Eğitim, Bilim ve Kültür Örgütü (UNESCO) 2016 y1lında mutlu okulun nelere dayandığına ilişkin bir rapor yayınlamıştır. Bu rapor Asya-Pasifik bölgesinde 30 farklı ülkenin ilköğretim ve ortaöğretim okulu öğretmenleri, öğrencileri, aileleri, okul yönetimi ve okul görevlileriyle yapılmıştır. 650 kişi ile yürütülen anket çalışmaları sonuçlarına göre mutlu okul için insanlar, süreç ve mekan ana kategorileri çerçevesinde 22 kriter belirlenmiştir. Mutlu okul ortamı için insan kategorinde altındaki kriterler okul topluluğu içerisindeki arkadaşlıklar ve ilişkiler, olumlu öğretmen tutumu ve nitelikleri, farklılıklara ve çeşitliliklere sayg1, olumlu ve işbirliğine dayalı değerler ve uygulamalar, öğretmen becerileri ve yeterlikleridir. Süreç kategorisi içerinde ise mantıksal ve adil iş yükü, takım çalışması ve işbirliği ruhu, eğlence ve öğrenme-öğretim yaklaşımlarının iç içe olması, öğrenen özgürlüğü, yaratıcılık ve katılım, başarma ve üstesinden gelme duygusu yaşama, müfredat dışı aktiviteler ve okul etkinlikleri, öğretmenler ve öğrencilerin bir takım olarak öğrenmesi, kullanışlı ve güncel öğrenme içeriğinin bütünleştirilmesi, zihinsel iyi oluş ve stres yönetimi kriterleri yer almaktadır. Mekan kategorisi içerisinde sıcak ve samimi öğrenme ortamı, akran zorbalığından uzak güvenli bir çevre, açık ve yeşil öğrenme ve oyun alanları, okul vizyonu ve liderliği, olumlu disiplin, sağlıklı olma, iyi bir sağlık ve beslenme hizmetleri, demokratik okul yönetimi kriterleri yer almaktadır. UNESCO raporuna göre çocukların okul ortamında mutluluğunu sağlayacak olan kriterler geniş bir çerçevede ele alınmıştır. UNESCO raporunda belirtilen kriterler bu araştırmanın sonuçlarını da kapsamaktadır.

\section{Sonuç ve Öneriler}

$\mathrm{Bu}$ araştırma sonuçlarına göre ortaokul öğrencilerinin çalışma baskısı yaşaması, öğrencinin kendini değerli ve önemli hissetmesi, okula yönelik duyguları, beklentiye karşı umutsuzluk duygusu yaşaması, öğretmenleriyle olan ilişkileri birlikte öğrencilerin mutluluk düzeylerini açıklamaktadır. Ortaokul öğrencilerinin mutluluk düzeylerini yordayan değişkenlerin belirlenmesinin araştırmacılar, öğretmenler, aileler ve en önemlisi de öğrenciler açısından yararlı olacağı düşünülmektedir. Bundan sonra yapılacak olan 
çalışmalar için ortaokul öğrencilerinin mutluluk düzeylerini daha geniş bir çerçevede ele alan, daha fazla değişkenin modele dahil edildiği araştırmaların yapılması araştırmacılara önerilebilir. Rehber öğretmenlere,öğrencilerin mutluluk düzeylerinin belirleyicisi olan değişkenlerle ilgili bilgi edinmeleri önerilebilir. Rehber öğretmenler öğrencilere, öğretmenlere, okul yönetimi ve ailelere destek sağlayarak mutlu okulların oluşmasında önemli bir rol oynayabilirler. Öğretmenler, öğrencilerin mutlu veya mutsuz olmalarında etkili olabileceklerininfarkında olmalı, öğrencilerle sağlıklı ve sıcak iletişim kurmalı, nitelikli olmalı, öğrencilerin okula yönelik olumlu tutum geliştirmelerini sağlamalıdırlar. Benzer şekilde okul yönetimi de öğrencinin okul ortamında mutlu olması için gerekli düzenlemeleri yapmalı ve öğrencilerin okula yönelik olumlu tutum geliştirmelerini hedeflemelidir. Aileler ise çocuklarından yüksek beklentiler içerisinde olmamalı, çalışma konusunda baskıcı bir tutum sergilememeli, çocuklarının değerli ve önemli olduklarını onlara her zaman hissettirmelidirler.

\section{Kaynaklar}

Adıgüzel, A. (2012). Okula ilişkin tutum ölçeğinin geçerlik ve güvenirlik çalışması. Elektronik Sosyal Bilimler Dergisi, 11(40). 30-45.

Akın, A. (2013).Güncel psikolojik kavramlar-1. Pozitif psikoloji.Sakarya: Sakarya Üniversitesi Eğitim Bilimleri Enstitüsü Yayınları.

Ayık, A. Ataş-Akdemir, Ö. (2015).Öğretmen adaylarının okul yaşam kalitesi ve okula yabancılaşma algıları arasındaki ilişki. Kuram ve Uygulamada Ĕ̈itim Yönetimi. 21(4). 429-452.

Bird, J. M., \&Markle, R. S. (2012). Subjective well-being in school environments: promoting positive youth development through evidence-based assessment and intervention. American Journal of Orthopsychiatry, 82, 61-66.

Büyüköztürk, Ş. (2012). Sosyal bilimler için veri analiz el kitabı (17.Bask1). Ankara: Pegem Akademi.

Büyüköztürk, Ş. Çakmak, E.K., Akgün, Ö.E., Demirel, F. Karadeniz, Ş. ve Demirel, F. (2009). Bilimsel araştırma yöntemleri(3. Basım). Ankara: Pegem Akademi Yayıncılık.

Can, A. (2014). SPSS ile bilimsel araştırma sürecinde nicel veri analizi. Ankara: Pegem A Yayıncılık.

Çevik, N. (2010). Lise ögrrencilerinin öznel iyi oluşlarını yordayan bazı değişkenler. Yayınlanmamış Yüksek Lisans Tezi. Gazi Üniversitesi, Eğitim Bilimleri Enstitüsü. Ankara.

Cheng, S. \& Chan, A. (2003). The development of a brief measure of school attitude.

Educational and Psychological Measurement. 63 (6). 1060-1070.

Çokluk, Ö., Şekercioğlu, G., Büyüköztürk, Ş. (2014). Sosyal bilimler için çok değiş̧kenli istatistik SPSS ve LISREL Uygulamaları. (4.Baskı). Ankara: Pegem Akademi.

Demirci, N., Engin, A.O., Bakay İ. ve Yakut, Ö. (2013). Stres ve stresi ortaya çıkaran durumların öğrenci üzerindeki etkisi. Ĕgitim ve Öğretim Araştırmaları Dergisi.3(2), 288-295.

DeNeve, K.M.,\&Cooper, H. (1998). The happy personality: A meta-analysis of 137 personality traits and subjective wellbeing. Psychological Bulletin, 124, 197-229

Diener, E. (1984). Subjective well-being. American Psychological Assosication, 95 (3), 542-575. 
Diener, E., Oishi, S., \& Lucas,R. E. (2002). Subjective well-being: The science of happiness and life satisfaction. C.R. Snyder \& S.J. Lopez (Ed.), Handbook of Positive Psychology. Oxford and New York: Oxford University Press.

Doğan, T. ve Eryılmaz, A. (2013). İki boyutlu benlik saygısı ve öznel iyi oluş arasındaki ilişkilerin incelenmesi. Pamukkale Üniversitesi Ë̆itim Fakültesi Dergisi, 33 (I), 107-117.

Döş, İ. (2013). Mutlu okul. Eğitim ve Bilim. 38 (170). 266-280.

Erdoğan, İ. (2011). Sinıf yönetimi: Ders, konferans, panel ve seminer etkinliklerinde başarının yolları (14.Basım). İstanbul: Alfa Yayım Dağıtım.

Erkman, F., Caner, A., Sart, H.Z., Börkan, B \&Şahan, K. (2010). Influence of perceived teacher acceptance, self-concept, and school attude on the academic achievment of school age children in Turkey. Cross Cultural Research. 44(3), 295-309.

Gordon, T. (2013).Etkili öğretmenlik eğitimi (5.Baskı). (S. Karakale, Çev.). İstanbul: Profil Yayıncılık.

Kalaycı, Ş. (2014). SPSS Uygulamalı çok değişkenli istatistik teknikleri. (6.Baskı). Ankara:Asil Yayın Dă̆ıtım.

Karatzias, A. Chouliara, Z. Power, K. \& Swanson, V. (2006). Predicting general well-being from self-esteem and affectivity: An exploratory study with Scottish adolescents. Quality of Life Research.15, 11431151.

King, K., Vidourek, R.A., Merianos, A.L., \& Singh, M. (2014). A study of stress, social support, and perceived happiness among college students.The Journal of Happiness \& Well-Being, 2(2), 132-144

McCabe, K., Bray, M.A., Kehle, T.J., Theodore, L.A. \&Gelbar, N.W(2011). Promoting happiness and life satisfaction in school children. Canadian Journal of School Psychology. 26(3), 177-192.

Natvig, G.K., Alberktson, G. \& Ovarnstrom, U. (2003). Associations between psychosocial factors and happiness among school adolescents. International Journal of Nursing Practice, 9, 166-175.

Önder, C.F. ve Sarı, M. (2009). Öğretmenlerde öznel iyi olmanın yordayıcıları olarak okul yaşam kalitesi ve tükenmişlik. Kuram ve Uygulamada Ĕgitim Bilim. 9(3). 1205-1236.

Özdemir, Y. ve Özdemir, M. (2015). Eğitim stresi ve benlik saygısının ortaokul öğrencilerinin okul tükenmişliği üzerindeki doğrudan ve dolaylı etkileri. Adnan Menderes Üniversitesi Eğitim Fakültesi Ĕ̈itim Bilimleri Dergisi.6(2), 1-10.

Sarı, M. (2007). Demokratik değerlerin kazanımı sürecinde örtük program: Düşük ve yüksek 'okul yaşam kalitesine sahip' iki ilkögretim okulunda nitel bir çalışma. Yayınlanmamış Doktora Tezi. Çukurova Üniversitesi. Sosyal Bilimler Enstitüsü, Adana.

Sarı, M. (2012a). Okul yaşamının değerlendirilmesi. Okul yaşam kalitesi ölçeğinin güvenirlik ve geçerliği. Hacettepe Üniversitesi Ĕ̌itim Fakültesi Dergisi. 42: 344-355. 
Sarı, M. (2012b). Empatik sınıf atmosferi ve arkadaşlara bağl1lık düzeyinin lise öğrencilerinin okul yaşam kalitesine etkisi. Kuram ve Uygulamada Ĕ̈itim Yönetimi. 18(1), 95-119.

Seçer, İ. Veyis, F. ve Gökçen, R.A. (2015). Eğitim stresi ölçeğinin türk kültürüne uyarlanması: güvenirlik ve geçerlik çalışması. Illkögretim Online. 14 (1).

Tabachnick, B. G. \&Fidell, L. S. (2007). Using multivariate statistics. (5. Bask1). New York: HarperCollins.

Telef, B.B. (2014). Okul çocuklarının mutluluk envanteri: geçerlik ve güvenirlik çalışması. International Online Journal of Educational Sciences. 6(1), 130- 143.

Türkdoğan, T., (2010). Üniversite öğrencilerinde temel ihtiyaçların karşılanma düzeyinin öznel iyi oluş düzeyini yordamadaki rolü. Yayınlanmamış Yüksek Lisans Tezi. Pamukkale Üniversitesi Sosyal Bilimler Enstitüsü, Denizli

UNESCO (2016). Happy Schools, A framework for learner well-being in the Asia-Pacific. Fransa: Paris.

Ünal, S. ve Ada, S. (1999). Öğretmenlik mesleğine giriş. İstanbul:Marmara Üniversitesi Matbaa Birimi.

Yavuzer, H. (2004). Çocuk eğitimi el kitabı. (17.Baskı). İstanbul: Remzi Kitapevi.

Yavuzer, H. (2011). Çocuk psikolojisi (33.Bask1). İstanbul: Remzi Kitapevi.

Yılmaz, A. (2001). Sınıf içi öğrenci-öğrenci etkileşiminin öğrenme ve sosyal gelişim üzerindeki etkileri. Kuram ve Uygulamada Ĕ̈itim Yönetimi. 25, 147-158.

Wilks, S. E. (2008). Resilience amid academic stress: the moderating 1mpact of social support among social work students. Advances in Social Work, 9(2), 106-125.

\section{Extended Abstract}

\section{Purpose}

One of the prerequisites for academic, social and psychological development of children who will create the future of societies is for them to feel happy and safe at their schools. Happiness of school children is defined as positive emotional experience which results from the consistency between individual needs and expectations from school in relation to certain environmental factors. Throughout school life, stress factors threatening students emerge as workload, exam stress, success anxiety, great expectations and pressure of family. It is well known that stress factors affect psychological well-being of individuals. One of the indicators for general well-being conditions of children is the quality of school life. Quality of school life is related to reactions of students including the attitudes of students towards their teachers, their general satisfactions from school and dedication to school. Quality of school life has been analyzed by the researchers in line with different dimensional classifications. In this research, quality of school life is considered as the status related to teacher-student relations, student-student relations, emotions towards school and school administration and how valued and important children feel themselves at school. The feeling of happiness in school setting leads to achievement in both academic and social field. Therefore, it is 
considered to be important to analyze the variables which predict happiness. In previous studies, happiness levels of students were discussed respectively in relation to stress, teacher relations, peer support, attitudes toward the school and self-esteem. However, in literature no study has been encountered about predicting the happiness level of students in which happiness related variables are taken into consideration altogether. This study aims to reveal whether both educational stress and quality of school life together predict the happiness of middle school students at school setting at a significant level.

\section{Method}

Analyzing the prediction level of educational stress and quality of school life on happiness of middle school students, this study adopted correlational research method. Demographic features of the participants' such as gender, age and class level were collected through the personal information form which was developed by researchers. Educational Stress Scale was conducted in order to measure stress levels of students (which stem from academic reasons) in the age range of 12-18 years. This scale has a four dimensional structure which includes the following subscales: study pressure, workload, success anxiety and desperateness towards expectancy. Quality of School Life Scale was used in order to measure students' perceptions about school life. This scale has five dimensions which include the following subscales: teachers, students, affects towards school, administrator and status. School Children's Happiness Inventory was used in order to measure the happiness level of middle school students at school. The sample of this research consists of 411 students studying during 2015-2016 academic year at four different middle schools which were randomly selected among state schools in a city center located in Mediterranean Region in Turkey. The mean age of these students was 12.53 and their age ranges from 10 to 16 . During data analysis process, after examining basic assumptions of multiple regression analysis, it was decided that assumptions had been met for this analysis. Therefore, multiple regression analysis was found to be appropriate for analyzing the predictive level of educational stress and school life quality on happiness of middle school students. Specifically, stepwise regression was chosen among multiple regression analysis methods.

\section{Results}

Educational stress was measured in line with the dimensions of study pressure, workload, success anxiety and desperateness of expectancy; while quality of school life was measured in line with the dimensions of teachers, students, affections towards the school, administrator and status. The teachers dimension is related to the quality of interaction between teachers and students and then self-development levels in professional field; students dimension is related to the quality of students' interaction among themselves. Affections towards school dimension include both positive and negative emotions towards school. Administrator dimension is associated with the quality of interaction between school administrators and students, how much emphasis administrators put on student involvement, their sensitivity level to problems of students at school. Status dimension is associated with to what degree students feel valued and important accorded by significant others within the school. 
According to regression model -which is used for determining whether educational stress and quality of school life predict the happiness level of middle-school students, it was revealed that study pressure, status, affections towards the school, desperateness of expectancy in addition to dimension of teachers which were included into model explained \%31 of happiness level of middle school students. This model was used as a base because the highest variance was explained with five variables. Consequently, study pressure, status, affections towards the school, desperateness of expectancy and teachers dimension altogether which were incorporated into model predict the happiness level of middle school students at 0.01 significance level. According to this model, it is possible to put an order in terms of relative significance rank and the order depending on significance levels among middle school students' happiness predictors is as follows: "study pressure, status, affections towards school, desperateness of expectancy, teachers". These five variables altogether which are incorporated into model (study pressure, status, affections towards school, desperateness of expectancy, teachers) display a significant relationship at medium level with happiness level of middle school students.

\section{Discussion}

A negative significance correlation at medium level was found between study pressure and desperateness towards expectancy dimension which respectively fall within happiness level of middle school students and educational stress. In other words, too much pressure on students which stem from studying, great expectations of families and despondency of students about academic failure was found to have a negative impact on the happiness in middle school students. Study pressure and desperateness of expectancy are sources of educational stress. Therefore, it is possible to assert that middle school students are getting unhappier as a result of an increase in educational stress. The results of various studies report that the students' happiness level is low if their stress level is high. It is well known that students who are identified as having low level happiness perception possess much higher stress levels. According to results of this study, among sources of educational stress, two major dimensions -study pressure and desperateness of expectancy- are found to be significant predictors of happiness level of middle school students, however success anxiety and workload dimensions fail to predict the happiness level at a significant level.

The research results in literature indicate that there is a positive significant relationship at medium level between the happiness of middle school students and respectively the dimensions of status, affections toward the school and teachers in quality of school life scale. It is possible to claim that the students feeling valued and important in school environment are happier in school setting, have positive affections towards the school and maintain intimate relations with teachers. The status dimension -second significant predictor in order of importance related to middle school students' happiness level- is associated with students' feelings of worthiness and importance accorded by significant others within the school. Individuals' sense of being qualified, valued and important as a person is conceptualized as self-respect. In studies conducted so far, it has been revealed that there is a positive significant relationship between happiness level and self-respect which is an important predictor of happiness. Additionally, studies in related literature demonstrate that there 
is a strong relationship between subjective well-being and self-respect. Positive and supportive school environment emerges as another factor which plays an important role on happiness of children at school. The attitudes and emotions of children towards the school have been analyzed in dimension of affections towards the school. Many studies conducted to date reveal that attitude towards the school is closely related to academic achievement. However, by means of this study, it is also indicated that affections towards the school directly affect well-being of children at school setting in addition to their academic achievement. Due to the crucial impact of school on students' academic, social and psychological outcomes, it becomes an important priority to provide students with the opportunity of enjoying school setting and having satisfactory experiences at school. Especially, teachers have a serious responsibility for guiding experiences of students in their school life. Teachers have a fundamental role on students' enjoying the course, developing good studying habits, adopting new value judgments and attitudes, their self-actualization and personality development. The results of this study also support the notion that teachers play an important role on students' happiness at school. Studies demonstrate that social support given by teachers and peers increases happiness of students at a significant level. In these studies, both teacher support and peer support have positive significant relation with students' happiness level; however, teacher support is found to be more important compared to peer support. According to the results of this study, student-student relationship makes no significant contribution to the model which explains the happiness level of middle school students. According to the results of this study, school administrator also makes no significant contribution to the model.

\section{Conclusion}

The determination of the variables predicting the happiness level of middle school students is considered to be beneficial for researchers, teachers, parents and most importantly students. For further studies, it can be suggested to researchers to conduct studies which approach the happiness of middle school students in a broader framework and include more variables into model.

It can be recommended to school counselors to get more information on the variables determining the happiness level of school children. School counselors can play a fundamental role on creation of happy school settings by giving professional support and guidance to students, teachers, school administrators and parents. Teachers should be aware of the fact that they can be effective in happiness or unhappiness of students. Additionally, they should be qualified and eligible, create intimate and healthy relations with students and help them develop positive and favorable attitudes towards the school. Likewise, school administrator should make necessary arrangements in order to provide happiness of students at school setting and set goals for promoting them to develop positive and favorable attitudes towards the school. Lastly, parents should not be in great expectations for their children, not display authoritative and oppressive attitudes related to studying and most importantly families should make it evident for their children that they are always and unconditionally invaluable and important. 